\title{
"My experience in life is that you should be careful with most people and not trust them too much"1
}

- Social trust among recipients of voluntary welfare in Norway

Therese Saltkjel, Research Assistant, Oslo University College, Faculty of Social Sciences, Social Welfare Research Centre, Norway. 


\begin{abstract}
:
The significance of social capital, including social trust, has in recent decades been acknowledged by many scholars across different disciplines as a key resource. This has led to many studies and scientific articles investigating this topic. Few studies, however, have focused upon social trust within marginalised groups. This study is based upon data gathered from one of the larger research projects investigating the vulnerable recipients of voluntary welfare assistance in Norway. The aim of the study is to investigate the level of social trust in a sample of 80 recipients of welfare assistance within two large voluntary welfare organisations in the capital city of Oslo, Norway. In particular, the study will explore whether and to what degree the level of social trust can be explained by conditions experienced while growing up and as an adult. Results indicate that adult life experiences, such as drug abuse and life satisfaction are the most important explanatory variables. However problems experienced while growing-up seems to be indirectly related to social trust. The results of the study highlight the significance of acknowledging processes of marginalisation in socially vulnerable groups, such as drug users and children experiencing problems growing up.
\end{abstract}

\title{
Keywords:
}

Recipients of voluntary welfare assistance, social trust, early life socialization, success and well-being marginalised groups

\section{Introduction}

The concept of trust has rich traditions within philosophy and ethics and within social and political thought (Sztompka 1999). Almost all research shows that trust contributes to positive outcomes at many levels, including individuals, communities, workplaces, institutions and nations (Welch et al. 2005).

The concept of trust is related to a longstanding tradition in American political culture that focuses upon civil society and its significance for social integration, social cohesion and democracy (Trägårdh 2008; Selle 2008; Boje 2008).

The source of trust can be explained by cultural or by institutional theories. One cultural theory views social trust as a stable value and a product of early life socialization (Uslaner 2002). Other perspectives view social trust as a result of success and well-being in adult life (Delhey \& Newton 2003). These theories appear to converge, because one normally assumes that early life socialization produces well-being and success later on in life.

Focusing on Norway, previous cross-national comparative studies have showed high levels of social trust in Norway (Rothstein and Stolle 2003; Halvosen 2007), thus the Norwegian citizens seem to be a trusting people. Other studies however focusing on marginalised groups, such as longer-term social assistance recipients, showed that the level of social trust was substantially lower than among the general Norwegian population (Slagsvold \& van der Wel 2006). One important empirical question therefore is whether this low level of trust also can be identified among other marginalized people within the Norwegian society.

Another study showed that social conditions while growing-up and adult life experiences were associated with the level of social trust. Within the category of adult life experiences, drug abuse was particularly associated with the level of social trust (Malmberg-Heimonen 2008). However, these studies all focused upon longer-term social assistance recipients. Recipients of welfare assistance from voluntary welfare organizations were not included in any of the above studies. As a consequence, the aim of this study is to investigate the level 
of social trust in a sample of Norwegian voluntary welfare assistance recipients and to study whether and to what degree early life socialization and adult life experiences contribute to explain the variation in social trust within individuals in this group. Since there is a lack of research on this specific group of recipients, this study is important. The study also contributes to the sparse research on social trust undertaken within marginalised groups which are difficult to reach by representative survey studies (Ringdal 2001).

The voluntary welfare organizations included in this study (the Salvation Army and the (Lutheran) Church's City Mission) offer low-threshold services to people in need of help and supports, including food distribution, places to meet and vocational activities for people who have problems of drug abuse. Overall, these services should be seen as being a "last resort" in cases where public welfare services, for various reasons, do not meet the basic needs of individuals. Consequently, one may assume that the study participants are in a more vulnerable position compared to recipients of public welfare assistance.

Viewing social trust as an important 'asset' both for societies and individuals, knowledge about the sources of trust within a group of voluntary welfare recipients can be of both scientific and political interest. This in a country where social trust is stable at a high level and the responsibility for the citizens well being and safety rests up-on the welfare state. If marginalized groups within the Norwegian society also are systematically marginalized when it comes to social trust it can be viewed as a sign of depend social division between high status and low status groups. Knowledge about the sources of trust within this particular group of citizens, can contribute to knowledge-based policies and measures as how to facilitate the development of social trust in one group not fully included by the encompassed welfare state.

\section{Social trust as a theoretical concept}

There are different forms of trust and some will be briefly introduced here. This study is however about the social trust and its determinants. The main approaches will be briefly introduced here (cultural versus institutional theories). The two theories (within the cultural approach) applied in this study will be accounted for in a more elaborated way.

A division is often made between particular and social trust. Particular trust is about trusting people who are similar to you. This form of trust often arises in closed social groups (Uslaner 2002). Social trust is more extensive. In addition to trusting people who are similar to you, social trust includes trusting strangers (Halvorsen 2007). Social trust is about trusting people across established social ties (Tjerbo \& Hansen 2005).

The different theoretical approaches to the concept of trust emphasize different dimensions in regards to what creates and what undermines trust. Mishler and Rose (2001) differentiate between cultural theories and institutional theories. Ordinarily, an important distinction is made between micro and macro perspectives within cultural and institutional theories.

Cultural theories argue that individuals learns to trust or distrust others by experiencing how other people in the culture treat them, and how other people react to their behaviour. Given this cultural perspective, institutional trust is seen as being an extension of social trust, which is learned early in life and then later is projected to political insitutions (Mishler \& Rose 2001). According to well known researcher of social capital, Robert Putnam, social trust is projected to political institutions and this projection thereby creates a civic culture (Mishler \& Rose 2001).

Institutional theories argue that a rational assesment of the different political institutions is made and that assessment grounds the trust or distrust of institutions by individuals. 
Proponents of these theories disagree about the aspects of institutions that are most relevant, and how they should be evaluated (Mishler and Rose 2001). For example, some proponents believe that contacts with universal welfare institutions are important in shaping the social trust that people incorporate (Rothstein \& Stolle 2001). According to this view, contacts with institutions that implement public policies, like municipal social services, health services, and employment offices etc. create or, alternatively, undermine institutional trust, which "spills over" to generate the social trust or distrust that person has in other people. When citizens perceive that they are being treated in an impartial and fair way, they experience institutional trust and this raises the level of their social trust (Rothstein \& Stolle 2001).

The cultural theory developed by Eric Uslaner (2002) argues that social trust has moral foundations and is the result of childhood learning. According to this social psychological theory, social trust is viewed as being a fundamental personality characteristic. This characteristic is based upon the trust that is learned in the early stages of socialization. The social trust that is characteristic of a particular personality can be changed later in life, but when it does, the changes are due to repeated experiences or traumatic incidents. Uslaner (2002) argues that social trust is generated by an optimistic worldview, which we learn from our parents, to a greater extent than from objective living conditions. In opposition to the arguments put forward by Putnam, social trust has to be learned, not experienced. Social trust does alter slowly, however, and consequently must be viewed as a combination of the values we learn as children and the ideals we acquire later in life. Uslaner also argues that social trust is not dependent upon the experience of reciprocity (Delhey \& Newton 2003). In addition to optimism, ideas about being able to control your own destiny are important (Pearlin \& Schooler 1978). The optimist believes that tomorrow will be better because he or she has the possibility of making it better (Uslaner 2002). According to Uslaner (2002), optimists believe that their destinies are in their own hands, while pessimists do not believe that they have any control over the world. Pessimists envision a dark future that is beyond their own control. Uslaner's (2002) research findings provide empirical data which show that measures of optimism and high scores in measures of the degree to which one believes that your destiny is in your own control are positively associated with social trust. This view is supported in Malmberg-Heimonen's study (2008), which demonstrated associations between social problems while growing up and the level of social trust among longer-term social assistance recipients.

Another cultural theory makes the claim that social trust is a result of experiences of success and well-being during adulthood. The success and well-being theory emphasizes that socio-economic characteristics like class, income, age, gender, education, health etc., and well-being variables like life satisfaction, explain variations in social trust (Delhey \& Newton 2003). According to this theory, it is the winners in society who are the ones with the highest degree of social trust. The winners are people who have higher education, higher income, higher status and higher levels of subjective well-being. The losers are people who don't. Losers or have-nots are less trusting and more suspicious towards other people (Putnam 2000:138; Delhey \& Newton 2003). This view is, to some extent, supported by Hansen \& Tjerborg (2003) and Hyggen (2006), whose findings show that education has a positive and significant association with trust. In addition, a study by Stolle (2001) that focuses upon social trust and participation in voluntary organizations shows that indicators of success, such as income and education are associated with a higher level of trust. On the other hand, the study by Delhey \& Newton (2003) shows that subjective measures of success and well-being, such as life-satisfaction, have even stronger associations with trust than more objective measures of success, such as the standard of living or income. Research has also demonstrated that marginalised groups, such as longer-term recipients of social assistance, have a low level of social trust when this group is compared to the general population. In addition, research has demonstrated that the longer the duration 
of unemployment, the lower the level of social trust (Slagsvold \& van der Wel 2006). Another study has also demonstrated that socio-economic factors like material poverty, low education, being convicted of committing a crime and especially drug abuse is associated with a low level of social trust (Malmberg-Heimonen 2008).

\section{The case of Norway}

The interest in the concept of social trust can be related to understandings of, and research about civil society and the schools of thought that emphasize theories of 'social capital'. Dominant American views on the relationship between the state and civil society characterize that relationship as one of hostility, and this has given rise to a neoliberal thesis, sometimes called, the "crowding-out" thesis. According to this thesis, the relationship between the state and civil society can be characterised as a 'zero-sum game'. That is, the more extensive and powerful the state is, the less extensive and less powerful is civil society. When this view is applied to the Scandinavian context and history, the picture of a conflicting relationship between the state and civil society, however, does not quite fit (Trägårdh 2008; Selle 2008; Boje 2008). By and large, in the Scandinavian countries, the citizen's individual rights and obligations are directly related to the state, independent of family, relatives and civil society (Esping-Andersen 1990). In Esping-Andersen's words: "The ideal is not to maximize the dependency on the family, but the capacities for the individual's independence" (ibid, p.28). Hence, what characterises the egalitarian societies of the Scandinavian countries, including the Norwegian welfare state, is that the relationship between the state and its citizens can be viewed as an alliance. The strong relationship between the state and its citizens has provided the individual citizen with great autonomy across traditional social divides like class, gender etc. (Trägårdh 2008; Selle 2008). This has led to an alternative thesis, a "complimentary thesis" (Boje 2008), where the relationship between state and civil society can be described as a 'plus-sum game'. At present, there are several examples of empirical research and interpretive literature that supports this thesis (Rothstein \& Stolle 2003; van Oorshot \& Arts 2005). Countries with high public spending have higher national levels of social trust, a higher degree of trust in institutions, a higher degree of participation (both active and passive) in voluntary organisations etc. (Van Oorschot \& Arts 2005)

According to the dominating theory of civil society in the USA, civil society is viewed as being the bearer of moral practices and values. This idealised vision places a great deal of significance upon civil society. Civil society represents "the good society" (Trägårdh 2008:581), and it is ascribed a mediating function in the integration of society, by being a school for democracy and a channel for active citizen participation (Boje 2008). The discipline of social work has its roots in organizations within civil society (Levin 2004). However, organizations within civil society are bearers of values and ideologies that dominate society as a whole and may just as well represent paternalistic and suppressing forces (Selle 2008). This has also been the case within the discipline of social work, where charitable work once differentiated between "worthy and unworthy poor" (Levin 2004). The early development of social work in Norway has its roots in the charitable work generated by the sociologist and social reformer, Eilert Sundt, amongst others, in the middle of the $19^{\text {th }}$ Century, and in the Christian mission and temperance movement in the latter part of the $19^{\text {th }}$ Century (Levin 2004). One example is The Salvation Army, which to a considerable degree practiced social work in Norway from the end of the $19^{\text {th }}$ Century. After World War II, social work as a discipline fully established itself in Norway (Levin 2004:37). This development coincides with the establishment of the welfare state and the close relationship between the state and its citizens. Dependency upon the charity work undertaken by family, relatives, friends, and the more formal organizations within civil society has been diminished. In contemporary Norway, more than 50 percent of social workers are employed by public social services and child welfare services (Levin 2004). 
Despite the close relationship between the individual citizen and the state and the responsibility of the state to ensure the welfare and safety of all Norwegian citizens, some people either choose to, or are forced to turn to charitable organizations within civil society for help and support. This study attempts to illuminate aspects of this situation.

\section{The aim of the study}

The aim of this study is twofold. Based upon social-psychological theories and the research undertaken by Uslaner (2002), and earlier research findings (Malmberg-Heimonen 2008), the first aim is to analyze whether and to what extent the level of social trust among recipients of voluntary welfare support and services can be explained by early childhood socialization and by personality characteristics. Early childhood socialization is operationalised by questions relating to experiencing problems while growing up, while the example of a personality characteristic is operationalised by questions relating to the possession of hope. In accordance with the success and well-being theory and earlier research findings (Stolle 2001; Delhey \& Newton 2003; Tjerborg \& Hansen 2003; Hyggen 2006; Malmberg-Heimonen 2008), the second aim is to investigate whether and to what extent factors indicating the success and well-being in adulthood of study participants will be able to contribute to the explanation of variance in the levels of social trust. The explanatory variables used in the analyses are life satisfaction and the use of drugs.

\section{Material and methods}

This study is based on data from the research project entitled, «The welfare state seen from below», which is the largest of its kind in Norway concerning vulnerable recipients of help and support from voluntary welfare organizations. The data consists of interviews with 80 welfare recipients of help and support from voluntary welfare organizations in Norway during the fall of 2006. The informants were asked a series of questions with open and structured response alternatives. The questions asked were related to social background, problems that were experienced while growing-up, income, employment status, experiences with public welfare institutions and with voluntary organizations etc. For a more elaborate account of the data collection, see other publications in the project (Saltkjel 2007; Aaslund 2008; Larring 2008; Stjernø \& Saltkjel 2008).

We selected two institutions within two voluntary organizations for our study. The institutions have different functions and are, in varying degree, integrated within the public welfare services. Fretex (a thrift shop) and Oslo Slumstasjonen (The Oslo Slum Station) were chosen within the programs found in the Salvation Army. Bymisjonssenteret $i$ Tøyenkirken (The City Mission Center at Tøyen Church) and Lønn som fortjent (Deserved Pay) were chosen within the programs found in the (Lutheran) Church's City Mission.

The Salvation Army has activities in 111 countries and describes itself as "... an international movement and an evangelical part of the Universal Christian Church". The Salvation Army in Norway has 37 institutions providing different forms of social work and 45 Fretex stores $^{2}$. The Salvation Army has over 200 officers, 2,000 employees, and almost 6,000 soldiers. The (Lutheran) Church's City Mission is a major diaconal organization and has more than 1,300 employees and about the same number of volunteers in more than 40 different institutions and projects in the Oslo area $^{3}$.

\section{Characteristics of study participants}

There are more men than women among the study participants. The average age was 47 years, and about one-tenth reported having an ethnic minority background. Almost half of the study participants ( 45 percent) were single (unmarried/never been married/not cohabitant), and about a third were divorced or separated (33 percent). Only 11 percent 
of the study participants were married or were registered cohabitating partners (table not shown). Only one person among study participants answered that work was his or her main activity last week. About a third of the study participants were recipients of disability benefit. In addition, a fifth of the study participants participated in employment measures (20 percent), and 18 percent were unemployed and living on social assistance. A fifth was in vocational rehabilitation programs/receiving vocational benefit (21 percent). For more information about the characteristics of study participants see Stjernø \& Saltkjel (2008).

\section{Measures}

Morris Rosenberg developed a five point scale measuring "faith in people"4 (Rosenberg 1956; Uslaner 2002). Different versions of this scale are being used in several different large international surveys, eg. the European Social Survey (ESS 2007).The measure of trust was assessed by asking three questions. The responses were rated from 0 to 10 corresponding to the degree of agreement. The first question was assessed as follows: "Generally speaking, would you say that most people can be trusted, or that you can't be too careful in dealing with people?" The value 0 is: "you can't be too careful in dealing with people and the value 10 is: "Most people can be trusted". The second question was assessed as follows: "Do you think that most people would try to take advantage of you if they got the chance, or would they try to be fair?" The value 0 is: "Most people would try to take advantage of you" and the value 10 is: "They try to be fair". Finally, the third question was assessed as follows: Would you say that most of the time people try to be helpful or that they are mostly looking out for themselves?" The response value 0 is:" People are mostly looking out for themselves". The response value 10 is:" Most of the time people try to be helpful". An assessment of all three questions was included in a trust index measuring the level of social trust. The total score was divided by 3. I table 1 accumulated the responses into three groups. Mean scores ranging from 0 to 3.99 indicate a low level of social trust. Mean scores ranging from 4 to 6.99 indicate a medium level of social trust and mean scores ranging from 7 to 10 indicate a high level of social trust (Halvorsen 2007). Case summaries showed that three study participants had missing values on one or two of the items. Missing values on each item were replaced with the items mean value. The Cronbach Alfa of the index is 0.88 and the reliability of the index appears to be good (Ringdal 2001).

In this study we operationalise social trust according to several other studies, seeing that this measure is well tested and the validity and reliability has been assessed. There are several surveys and studies which can be used for cross-national and national comparison. Some scholars (Uslaner 2002) use only one of the three questions (trustfulness) when assessing social trust. Earlier Norwegian studies however have assessed trust based on all the three trust questions (Hansen and Tjerbo 2003; van der Wel et al. 2006; Halvorsen 2007).

We asked about the social problems that were experienced while growing up as follows: "Some have experienced problems growing up. Did you experience any of the following problems before the age of 16?" The responses were $0=$ "No" and "Yes" $=1$. There were 11 problems, such as; problems in school, economic problems in the childhood home, parents abusing drugs or alcohol, etc. Answers were summarized into an index with a range from 0 to 11 . All of the study participants had answered minimum 10 of the eleven questions; as a result all participants were included in the analysis. In the regression analyses the scale was reversed in the direction it was expected to correlate with social trust. A respondent that experienced all of the 11 problems before the age of 16 was given the value 0 . Study participants who experienced 10 of the problems received the value 1,9 problems the value 2 etc. (Solem 2003).

The hope index $(\mathrm{HI})$ is the short version of the Herths Hope Scale (HHS) and consists of 12 questions that measure various dimensions of hope. Examples from the assessment of 
the $\mathrm{HI}$ in our study are: "I have a positive outlook towards life", "I have short, intermediate, and/or long-range goals" and "I feel all alone". The responses were measured by a 4-point Likert scale that ranges from 1: "I strongly disagree" to 4: "I strongly agree" (Rustøen et al. 2003:311. According to Rustøen et al (2003) the validity of the measure were found satisfactory in different samples. The hope index has possible scores ranging from 12 to 48 , where a higher score indicates a higher level of hope (Rustøen et al 2003). Almost all of the study participants (79) had given an answer to 10 out of 12 items. One had given an answered 9 of the items. Missing values on each item where replaced with the items mean value before computing the index. The Cronbach Alfa of the index is 0.81 and the reliability of the index appears to be good

The use of drugs was asked as follows: "Think about your use of drugs the last 12 months. Include also the times you only used a little. Approximately how often have you used other drugs (than alcohol)?" The responses varied between 1: "Daily/almost daily" to 8: "Never" Overall life satisfaction was assessed by asking: "All things considered, how satisfied are you with your life as a whole these days?" Study participants were asked to give a value from 0 to 10 corresponding to the degree of agreement. The value $0=$ "extremely dissatisfied" and the value 10 = "extremely satisfied". The subject of life-satisfaction is part of a broader research field often referred to as Quality of life (Veenhoven, 1996:11). Despite critical discussions regarding the validity and the reliability of the measure, the simple closed end question, used in our study has been classified as an accepted indicator of overall life satisfaction (Veenhoven 1993; Diener et al 2002). Age and the level of education that had been achieved were measured with standard survey questions.

\section{Results}

A significance test of the mean social trust scores (index) for study participants in the four included institutions (one-way analysis of variance) indicated a low probability that there were any differences with respect to social trust between study participants utilizing these four institutions. As a consequence, social trust scores will be treated collectively in further analyses.

Table 1 indicates that more than one-fourth of the study participants ( 28 percent) had a low level of social trust, while 46 percent had a medium level of social trust and more than onefourth (26 percent) had a high level of social trust. The mean social trust score is 5.09 (cf. table 1 ). In a study based on data from European Social survey 2002, the mean social trust score in Norway was 6.53 (Halvorsen 2007). 
Table 1: Trust, problems growing up, hope, drug use, overall life satisfaction among recipients of voluntary welfare $(n=70-80)$.

\begin{tabular}{|c|c|c|}
\hline Trust (\%) & Low & 28 \\
\hline & Medium & 46 \\
\hline & High & 26 \\
\hline & Mean score & 5.09 \\
\hline & (n) & $(80)$ \\
\hline \multirow[t]{11}{*}{ Problems growing up (\%) } & Economic problems in childhood home & 36 \\
\hline & Conflicts between parents & 52 \\
\hline & Parents abusing alcohol or other drugs & 29 \\
\hline & Long-lasting bullying/victimization & 33 \\
\hline & Mistreatment or sexual abuse & 23 \\
\hline & Problems getting friends & 25 \\
\hline & Problems paying attention at school & 43 \\
\hline & Dropping out of school & 21 \\
\hline & Moved often & 19 \\
\hline & Gravely sick parents & 27 \\
\hline & $\begin{array}{l}\text { War or violence outside the family } \\
\text { (n) }\end{array}$ & $\begin{array}{l}13 \\
(76-80)\end{array}$ \\
\hline Hope & Mean score & 36.20 \\
\hline \multirow{9}{*}{$\begin{array}{l}\text { Used drugs during last } \\
12 \text { months (\%) }\end{array}$} & Never & 53 \\
\hline & Not during the last 12 months & 14 \\
\hline & Less frequent & 6 \\
\hline & Once a month & 1 \\
\hline & 2-3 times a month & 4 \\
\hline & Once a week & 1 \\
\hline & 2-3 times a week & 3 \\
\hline & Daily & 17 \\
\hline & (n) & (70) \\
\hline \multirow[t]{3}{*}{ Life satisfaction (\%) } & Low & 21 \\
\hline & Medium & 32 \\
\hline & $\begin{array}{l}\text { High } \\
\text { (n) }\end{array}$ & $\begin{array}{l}47 \\
(78)\end{array}$ \\
\hline
\end{tabular}

Many of the study participants have experienced social problems while growing up (cf. table 1). Examples of this are illustrated by the fact that one-third of the participants have experienced economic problems while growing up and as many as half have experienced conflicts between their parents. Furthermore, 29 percent have experienced parents abusing alcohol or drugs, and one-third have experienced being bullied/victimized when they where growing up. One- fourth of the study participants were exposed to mistreatment or sexual abuse and as many as one- fifth of the study participants (21 percent, cf. table 1 ), had dropped out of school.

Table 2 shows the associations between trust and early life socialization and the personality characteristic hope, and experiences of success and well-being in adult life. The models have all been tested for multi-collinearity and all VIF values (Variance Inflation factor) are less than 10. The average VIF value for all three models is not substantially greater than 1. Hence there is no cause for concern for multicollinearity with respect to the conducted analyses (Field 2005). 
The analyses were done in three steps. The first model includes social problems while growing up and the personality characteristic 'hope'. In Model 2, experiences in adulthood in the form of drug use and life satisfaction have been included. Finally, Model 3 includes all variables with respect to early life socialization and experiences as an adult. The controls included in all three models are, gender, age and years of education (cf. table 2).

Table 2: Social trust among recipients of voluntary welfare, linear regression, standardized coefficients (beta) $(n=65-77)$.

\begin{tabular}{|c|c|c|c|}
\hline & Model 1 & Model 2 & Model 3 \\
\hline Gender (man $=1)$ & -0.15 & -0.13 & -0.13 \\
\hline Age & 0.04 & -0.14 & -0.15 \\
\hline Education & 0.01 & -0.02 & -0.02 \\
\hline Problems growing up index & $0.28^{*}$ & 0.09 & \\
\hline Hope index & $0.32 * *$ & 0.05 & \\
\hline Using drugs & $-0.43^{* *}$ & $-0.39 * *$ & \\
\hline Life satisfaction & $0.33^{* *}$ & $0.29 *$ & \\
\hline Adj. $R^{2}$ & 0.16 & 0.31 & 0.29 \\
\hline (n) & $(77)$ & $(65)$ & $(65)$ \\
\hline
\end{tabular}

$* * * p>0.001,{ }^{* *} p>0.01,{ }^{*} p>0.05$

Table 2 shows that there is no significant association between gender and social trust. There is, however, a relatively strong trend which shows that women have a higher level of social trust compared to men. The results found for Model 1 show a significant positive association between early life socialization and social trust. In other words, study participants who have experienced fewer social problems while growing up have a higher level of social trust than study participants who have experienced a greater number of social problems while growing up. The results found for Model 1 also show a substantial and positive association between the hope index and social trust, i.e. participants who have a higher degree of hope have higher levels of social trust than participants who have less hope. The explained variance of the model is 16 percent.

In Model 2, experiences in adult life, i.e. drug abuse and overall life satisfaction have been included. The results show that drug abuse is significantly associated with lower levels of social trust. A substantial association between overall life satisfaction and social trust was also found. In other words, study participants who are less satisfied with their lives have a lower level of social trust compared to study participants who are more satisfied. The explained variance of the model is 31 percent.

In the final model (Model 3) all the variables are included. The results clearly show that early life socialization and the personality characteristic of hope are not statistically significant when controls are made for drug use and life satisfaction. Both of the success and well-being variables are positively associated with social trust. In this final model, the explained variance is 29 percent. The results for this final model clearly demonstrate that when controls are made for the variables 'early life socialization' and 'current life experiences', it is the latter perspective that continues to provide substantial findings.

Despite these main findings, it appears to be a relatively strong and significant correlation between hope and overall life satisfaction ( $r=.53$, cf. table 3, appendix), and between social problems experienced while growing up and use of drugs $(r=-.40)$. These correlations demonstrate a need for further interpretation of the results. 


\section{Discussion}

This study has examined levels of social trust in a sample of 80 study participants within two large voluntary welfare organizations. Based on results from previous studies, the aim was to investigate whether early life socialization and life experiences as an adult contribute to explain the variation in social trust found for this group of recipients of aid and supports from two voluntary welfare organizations. As such, this study has contributed to the scarce research on social trust among marginalized groups.

Results show that the levels of social trust among the recipients of voluntary welfare seems to be substantially lower compared to the trust level in a representative sample from the Norwegian population. In accordance with the psycho-social perspective, associations between problems experienced while growing-up, hope and social trust have been analysed. The results showed significant associations for these variables, which supports the psychosocial perspective that claims that early childhood socialisation is associated with social trust. The results also show significant associations between social trust, the use of drugs and overall life satisfaction. Consequently, the findings support the success and well-being theory that views social trust as the result of experiences of success and well-being in adult life. The findings also support Uslaner's view and research findings, i.e. the claim that a positive outlook on life, learned during early childhood socialization shapes social trust. These results are also in accordance with the findings from Malmberg-Heimonen's study (2008). Her study demonstrated associations between social problems while growing up and the level of social trust, as well as associations between drug use and social trust for longer term social assistance recipients. These results are also in accordance with Delhey \& Newton's (2003) findings, which show that subjective measures of success and well-being, for example, measures of self-reported life-satisfaction are associated with social trust.

Life satisfaction is an overall evaluation of life (Veenhoven1996). Establishing the determinants of life satisfaction is a complex matter involving several factors and processes. Determinants can be searched for at two levels; external conditions and psychological processes (Veenhoven 1996:5). One perspective is that we judge life from the "flow of life-experiences", with especially emphasise on the positive and the negative experiences (Veenhoven 1996:13). Interpreting trust according to the success and well-being approach implies en emphasizes on adulthood experiences (Delhey and Newton 2003).

In addition to the main findings, results show a relatively strong correlation between hope and life satisfaction. This correlation is stronger than the expected correlation between hope and trust (cf. table 2 and table 3, appendix). Life satisfaction is part of the concept and scientific discipline of subjective well-being. Our results are in accordance with earlier studies, where hope and optimism have been found to predict well-being, using a broad-band measure (Magaletta \& Oliver1999:544). Focusing on the roots of trust, the results does not seem to be in accordance with scholars who have labelled hope as an emotion with origins in early trust experiences with significant others (Erikson et al 1986). The result seem to be in accordance with other scholars who define hope as a multidimensional concept (cognitive-, affective-, contextual-, time-, attachment-, and behaviour dimension) (Wahl 2007:273), viewing it not as a stable property of the individual, but contingent by life experiences (Wahl 2007). As a result, one plausible interpretation of the results is that the participants hope might have important 'roots' in early childhood, but the connection to adult life experiences seems to be stronger.

As shown, social problems while growing up correlate significantly with social trust. When controls are made for drug use and life satisfaction, this association however disappears. Focusing on the psycho-social perspective, the association between problems experienced while growing up and drug use, indicates an indirect association between problems growing up and trust. 
The main finding of this study can be interpreted as supporting the view that experiences as an adult, to a greater extent than the learning imparted by early life socialization and personality characteristics, more profoundly contribute to explain the variance of social trust in this particular sample of voluntary welfare recipients. The result supports the view that the social trust acquired by these voluntary welfare recipients is due to their current life experiences, including drug abuse, and that social trust is an acquisition that can be revised and constantly changed. One important finding however is that early life socialication seems to affect well-being and success later on in life as there appear to be a relatively strong correlation between problems growing up and use of drugs. Thus these results indicate that the two theories converge. The findings of this study are, to a certain extent, supported by Uslaner (2002). Even though he argues that social trust is a stable moral value, shaped during the early stages of socialization and not dependent upon reciprocity, even he admits that social trust can be changed by repeated experiences and by traumatic circumstances. In the words of Putnam: "In virtually all societies "have-nots" are less trusting than "haves", probably because haves are treated by others with more honesty and respect" (Putnam 2000:138).

\section{Limitations}

There are empirical limitations concerning this study. Some of the limitations are related to the selection of variables in 'testing' the two trust theories. Other limitations are related to the study of 'rare' groups (Ringdal 2001).

In this study I used social problems experienced while growing-up as an indirect measure of early life socialisation. The underlying assumption is that problems experienced while growingup affect early life socialisation. It can be argued that the variable measures the quantity not he quality of the social problems. It is the cumulative effect which are emphasized; the more problems; the more negative effect on socialization and social trust. Further more there is no measure for the concept of optimism included in the study. Instead I have used a measure for hope. There are different ways to conceptualize and measure both constructs. Both hope and optimism are member of what has been referred to within the field of psychology as the "positive thinking family" (Snyder et al 2002:263). Optimism and hope have been found to be related, however not identical constructs (Magaletta and Oliver 1999). The concepts are related by a core of expectancies for the future, the persistence to reach outcomes or goals. In addition they are found to be powerful determinants for behaviour. They differ in that optimism includes expectancies about outcomes through others and forces outside the self, while hope includes expectancies about outcomes obtained by the self (Magaletta \& Oliver 1999:541). Both concepts have been related by some authors to early childhood and they emphasize strong and secure attachment to parental caregivers (Erikson et al 1986; Carver \& Scheier 1999; Snyder et al 2002). As the two constructs are related in several important ways, I have chosen to apply the measure of hope in the analysis.

The low number of participants in the study limits the number of variables that can be measured and analyzed. When choosing the variables I therefore had to be selective. One example is choosing drug use as an indicator of 'success and well-being', not the use of alcohol. Ideally I would use both indicators. There is little available research about the health and well-being of drug-addicts, drug abuse is however often associated with high risk of being marginalized, deprived and stigmatized in several ways (Rognerud, Strand \& Hesselberg 2000). Thus, the underlying assumption in selecting this indicator is that there in general is a stronger association between social problems and drug use, than between use of alcohol and social problems.

The first problem related to the study of 'rare groups is related to the selection and the second problem is related to the analysis (Ringdal 2001:111). The selection problem in this study is the fact that marginalized groups are difficult to reach for research 
purposes. Administrative data does not always exist for these groups. Individuals within these groups are hard to find, when research surveys that examine the living conditions of residents are undertaken. Consequently, it is difficult to obtain representative samples of marginalized groups, of which the recipients of aid and services provided by voluntary welfare organizations are one. In addition, the data in this study is cross-sectional. As a consequence, no truly causal relationships can be identified. Nevertheless, the retrospective emphasis on problems experienced while growing-up can, to some extent, indicate a causal-relationship, since childhood experiences necessarily occur long before adult study participants report on the social trust they have incorporated. Consequently, one may hypothesize a causal relationship. One important limitation is, however, the danger of recall-error, since study participants are asked to recall circumstances that happened a long time ago. It is important to note that recollections of the past cannot be treated as true reflections of an objective past (Field 1981:96). It should be noted that earlier research has found that factual information is recollected with greater agreement than attitudinal information (Field 1981).

The second main problem, the problem of analysis, is due to the fact that the analysis is limited to an analysis of the differences found within the selection. In addition, the study only has a small number of participants and this makes it very difficult to achieve statistically significant results. As mentioned earlier, the low number of participants also limits the number of variables that can be measured and analyzed. This makes it difficult to test theories and earlier research in a thorough and substantial way.

Given the uncertainty about whether or not the sample used in this study is a representative sample of recipients of the aid and services provided by voluntary welfare organizations, the sample does not fulfill the requirements that are needed to be able to make generalizations. The results should be interpreted with reservations and any generalizations made for the entire population of recipients of the aid and services provided by voluntary welfare organizations should be made with caution. Despite the limitations of this sample, however, the results do indicate plausible explanations for the low levels of social trust found in the marginalized group under study and several important trends have been identified. Given the difficulty obtaining representative samples of marginal groups this study should be regarded as having societal and scientific value.

\section{Policy implications}

To sum up, the results of this study have shown that the levels of social trust among the recipients of voluntary welfare seems to be substantially lower compared to the trust level in a representative sample from the Norwegian population. The social trust incorporated by participants is primarily due to (current) life experiences, more specifically, to drug (ab)use and to self-reported and subjective assessments of overall life satisfaction. It is, however, important to note that drug (ab)use does not characterize the group as a whole. In addition, the analyses that have been made do not rule out that other variables and other theories may also contribute to explain the level of social trust incorporated by the respondent. However, viewing social trust as a result of life experiences, to a greater extent than childhood learning and personality characteristics implies a less deterministic view in regards to what creates, alternatively, what undermines social trust, and gives reason for optimism because social trust can be created and incorporated as a result of new positive life experiences. However results indicate that early life socialication have an indirect effect on the social trust in this particular sample of voluntary welfare recipients, as there appear to be a relatively strong correlation between problems growing up and drug use. This is also important when adressing some of the policy implications that can be sifted from the research findings. 
This study indicates that those recipients of aid and services from voluntary welfare organizations that use drugs will have low levels of social trust. In Norway, all unauthorized use of narcotic drugs is defined as abuse ${ }^{5}$. This alone indicates that unauthorized drug use is strongly condemned and that users are stigmatised within Norwegian society. The Ministry of Health and Care Services has the responsibility for the overall coordination of all preventive and curative measures undertaken to provide help and services to people with alcohol and drug addictions ${ }^{6}$. The Norwegian National Action Plan on Alcohol and Drugs ${ }^{7}$, describes the committed actions to be taken by the Government in the area of alcohol and drug problems. The main objective is to "reduce the negative consequences of substance use for individuals and for society" (Ministry of Health and Care Services 2008:6).

Another important objective aims at making municipal services more accessible, by promoting the "greater social inclusion" of alcoholics and drug abusers (Ministry of Health and Care Services 2008:6). One measure described in the plan specifically attempts to promote social trust in the alcoholics and drug abusers that receive help and support from municipalities. The Government is trying out an initiative involving a trusted ally ("contact coordinators") (Ministry of Health and Care Services 2008:39-40). The trusted person will aid the alcoholic or drug abuser in getting the help and services that he or she needs within the public welfare support system. In addition, the trusted person will contribute to the efforts being made to insure that more and more people with alcohol and/or drug addiction problems are provided with an individual plan (Ministry of Health and Care Services 2008:39).

If this measure and other measures in the national action plan are properly implemented, there is reason to hope that this will contribute to the success of treatment initiatives, and to the improvement of welfare and living conditions for alcoholics and drug abusers in Norway. Properly implemented, the experience of having a trusted ally and a plan that has been tailor-made for one's own needs may be able to help people with alcohol or drug addiction who are forced to, or for some reason choose, to turn to voluntary welfare organizations for help, to bear the "costs" of trusting other people by creating the opportunity for new positive life experiences.

Measures to improve the lives and social conditions of drug users seem important. However, the results also indicate that early life socialization produces well-being and success later on in life among the recipients of the voluntary welfare. If early childhood problems among the recipients are the beginning of a course of events that can lead to the use of drugs and low levels of trust in adulthood, early intervention are of importance. Especially measures to reveal and/or prevent social problems for children and youth. In addition to kindergarden, school and health services, are important arenas to reveal bullying, different forms of neglect etc. Not least, good child welfare services.

\section{Acknowledgments}

The author whishes to thank the guest editor of Journal of Comparative Social Work, Associate Professor Anne Ryen (University of Agder), and two anonymous referees for valuable comments. In addition thanks to project leader, Professor Steinar Stjern $\varnothing$, for the permission to use the data from the research project «The welfare state seen from below». Thanks also to former colleagues at Oslo University College, Professor Knut Halvorsen, Associate Professor/Managing Director at GIV, Ivan Harsløf, PhD Student, Sille Ohrem Naper and Research Assistant Carolina Ohls, in addition Professor Sanford Schram, (Bryn Mawr College) for valuable comments and insights on a previous version. A special thanks to Associate Professor (Oslo University College), Ira Malmberg-Heimonen, for many valuable comments and input on previous versions of the article. The analyses and the interpretations are however the sole responsibility of the author. 


\section{Appendix}

Table 3: Correlations, means and standard deviations for social trust, gender, age, years at school/education, problems experienced while growing up, hope, drug use, and life satisfaction.

\begin{tabular}{|l|r|r|r|r|r|r|r|r|r|r|}
\hline & $\mathbf{M}$ & $\mathbf{S d}$ & $\mathbf{1}$ & $\mathbf{2}$ & $\mathbf{3}$ & $\mathbf{4}$ & $\mathbf{5}$ & $\mathbf{6}$ & $\mathbf{7}$ & $\mathbf{8}$ \\
\hline 1 Social trust $(n=80)$ & 5.09 & 2.53 & 1 & & & & & & & \\
\hline 2 Gender $(n=80)$ & 0.68 & 0.47 & -0.15 & 1 & & & & & & \\
\hline 3 Age $(n=80)$ & 47.35 & 10.73 & 0.12 & 0.04 & 1 & & & & & \\
\hline 4 School/education $(n=77)$ & 11.90 & 3.07 & 0.1 & 0.03 & 0.00 & 1 & & & & \\
\hline 5 Growing up problems $(n=80)$ & 7.83 & 2.73 & $0.28^{*}$ & -0.03 & $0.23^{*}$ & 0.15 & 1 & & & \\
\hline 6 Hope $(n=80)$ & 36.20 & 5.19 & $0.34^{* *}$ & 0.01 & 0.03 & 0.16 & 0.02 & 1 & & \\
\hline 7 Drug use $(n=70)$ & 2.91 & 2.72 & $-0.46^{* *}$ & 0.20 & $-0.33^{*}$ & -0.21 & $-0.40^{* *}$ & -0.22 & 1 & \\
\hline 8 Life satisfaction $(n=78)$ & 5.81 & 2.42 & $0.46^{* *}$ & 0.01 & 0.12 & 0.09 & 0.22 & $0.53^{* *}$ & -0.22 & 1 \\
\hline
\end{tabular}

\section{References}

Boje, Thomas P. "Velfærdsstat og civilsamfund: De nordiske lande i komparativt perspektiv". Tidsskrift for samfunnsforskning 2008: 595-609. Print.

Carver, Charles S. \& Michael. F. Scheier. "Optimism". In Charles R. Snyder, ed. Coping: The psychology of what works, New York: Oxford University Press, 1999, pp182-204.

Delhey, Jan \& Kenneth Newton. "Who trusts? The origins of social trust in seven countries". European Societies 5, No. 2, 2003: 93-137. Print.

Diener, Ed, Richard E. Lucas \& Shigehiro Oishi. "Subjective Well-Being: The Science of Happiness and Life Satisfaction" In Charles R. Snyder, \& Shane J. Lopez, eds Handbook of Positive Psychology, Oxford University Press. New York. 2002, pp 63-73.

Erikson, Erik H., Joan M. Erikson \& Helen Q Kivnick. Vital Involvement in Old Age. New York: W. W. Norton, 1986.

Esping-Andersen, Gösta. The three worlds of welfare capitalism. Cambridge: Polity Press, 1990.

European Social Survey. "Main Questionnaire". Europeansocialsurvey.org. Web.9. August 2009. http://www.europeansocialsurvey.org/index.php?option=com content\&view=article\&id $=63 \& \mid$ temid $=98$.

Field, Andy. Discovering statistics using SPSS: and sex, drugs and rock'n 'roll. ISM introducing statistical methods. $2^{\text {nd }}$ ed. London: Sage, 2005.

Field, Dorothy. "Retrospective reports by healthy intelligent elderly people of personal events of their adult lives". International Journal of Behavioural Development 4,1981: 77-97. Print.

Frelsesarmeen. "Nøkkelfakta". Frelsesarmeen.no. Web. 30. March 2009. http://www. frelsesarmeen.no/pages/side. $a s p x ? n r=2218$.

Halvorsen, Knut. "Legitimacy of welfare states in transitions from homogeneity to multiculturality: A matter of trust?" In Steffen Maus \& Benjamin Veghte, eds Social Justice, Legitimacy and the Welfare State, Aldershot: Ashgate, 2007, pp. 239-259. 
Hansen, Tore \& Trond Tjerbo. Politisk engasjement, borgerrolle og sosial kapital.

Unipubskriftserier, rapport nr. 62. Oslo: Makt- og demokratiutredningens rapportserie, 1998-2003, 2003.

. "Individualisme, sosial kapital og politisk deltagelse". Norsk statsvitenskapelig tidsskrift, No 1, 2005: 29 - 51. Print.

Helse- og omsorgsdepartementet. "Rusmidler Norge". Regjeringen.no.1 Aug. 2008.

Web. 23 Sept. 2008. http://www.regjeringen.no/nb/dep/hod/tema/rus/rusmidler-i-norge. html?id=439352.

Hyggen, Christer. "Risks and Resources: Social Capital among Social Assistance Recipients in Norway". Social Policy \& Administration 40, No. 5: 2006: 493-508. Print.

Kirkens Bymisjon. "The Church City Mission". Bymisjon.no. Web. 30. March 2009. http:// www.bymisjon.no/templates/Page 10432.aspx.

Larring, Kari Bakke. Sosial kapital blant marginaliserte. En studie av brukere i Kirkens

Bymisjon og Frelsesarmeen. Masteroppgave i sosialt arbeid. Oslo: Høgskolen i Oslo, 2008.

Levin, Irene. Hva er sosialt arbeid? Oslo: Universitetsforlaget, 2004.

Magaletta, Philip R. \& J. M. Oliver. "The Hope Construct, Will and Ways: Their Relations with Self-Efficacy, Optimism, and General Well-Being". Journal of Clinical Psychology, No 5, 1999: 539-551. Print.

Malmberg-Heimonen, Ira. "Sosial tillit blant langtidsmottakere av sosialhjelp: betydningen av fattigdom og oppvekstvilkår". In Ivan Harsløf \& Sissel Seim, eds Fattigdommens dynamikk. Perspektiver på marginalisering i det norske samfunnet Oslo: Universitetsforlaget, 2008.

Ministry of Health and Care Services. "Norwegian National Action Plan on Alcohol and Drugs". Regjeringen.no. Web. 30 March 2009. http://www.regjeringen.no/en/dep/hod/ documents/reports-and-plans/plans/2009/norwegian-national-action-plan-on-alcoho. $\underline{h t m l \text { ? id }=549775 .}$.

Ministry of Health and Care Services. "Alcohol and drug addiction". Regjeringen.no. Web.18 March 2009. http://www.regjeringen.no/en/dep/hod/Subjects/alcohol-and-drug-addiction. html?id=1130.

Mishler, William \& Richard Rose. "What are the origins of political trust? Testing Institutional and Cultural Theories in Post Communist Societies". Comparative Political Studies 34, No. 1, 2001: 30-62. Print.

Oorschot, Wim van \& Wil Arts. "The social capital of European welfare states: The crowding out hypothesis revisited". Journal of European Social Policy 15, No. 1, 2005: 5-26. Print.

Pearlin, Leonard I. \& Carmi Schooler. "The Structure of Coping". Journal of Health and

Social Behaviour 19, No. 1,1978: 2-21. Print.

Putnam, Robert. Bowling Alone: The Collapse and Revival of American Community. New York: Simon \& Schuster, 2000.

Ringdal, Kristen. Enhet og mangfold: samfunnsvitenskapelig forskning og kvantitativ metode. Bergen: Fagbokforlaget, 2001. 
Rognerud, Marit, Bjørn Heine Strand, Øivind Hesselberg. The Health of Disadvantaged Groups in Norway. Norwegian Country report for the EU Project. Rapport nr 2. Oslo: Statens institutt for folkehelse, 2000.

Rothstein, Bo \& Dietlind Stolle. Social Capital and Street-Level Bureaucracy: An Institutional Theory of Generalized Trust. Prepared for the ESF conference, Social Capital: Interdisciplinary Perspectives, Exeter United Kingdom, September 15-20, 2001. ."Introduction: Social capital in Scandinavia". Scandinavian Political Studies 26, No 1. 2003: 1-26. Print.

Rustøen, Tone, Astrid K. Wahl, Berit R. Hanestad, Anners Lerdal, Christine Miaskowski \&

Torbjørn Moum. "Hope in the general Norwegian population, measured using the Herth Hope Index". Pallative and Supportive Care 1, 2003: 309-318.

Salomon, Lester \& Helmut K. Anheier. "Social Origins Civil Society: Explaining the Nonprofit Sector Cross-Nationally". Voluntas: International Journal of Voluntary and Nonprofit Organizations 9, No. 3, 1998: 213-248. Print. Saltkjel, Therese. Tillit og utsatthet. Sosial og institusjonell tillit og mistillit blant brukere av det frivillige velferdsapparatet. Masteroppgave i sosialt arbeid. Oslo: Høgskolen i Oslo, 2007.

Selle, Per. "Forståinga av sivilsamfunnet. Er det berre opp til augo som ser?" Tidsskrift for samfunnsforskning No. 4, 2008: 613-624.

Slagsvold, Marit \& Kjetil van der Wel. "Sosial kapital". In Kjetil van der Wel, eds, Sille Ohrem Naper, Marit Slagsvold, Borghild Løyland, Ivar Lødemel \& Espen Dahl. Funksjonsevne blant langtidsmottakere av sosialhjelp, HiO-rapport nr 29. Oslo: Høgskolen i Oslo, 2006.

Snyder, Carles R. Kevin L. Rand \& David R. Sigmon."Hope Theory A Member of the Positive Psychology Family". In Charles R. Snyder \& Shane J. Lopez eds, Handbook of Positive Psychology. Oxford University Press. New York. 2002, pp.257-276.

Solem, Per Erik. Forskningsinstrumentene i NorLag. Oslo: NOVA, 2003.

Stjernø, Steinar \& Therese Saltkjel. "Gjennom det siste sikkerhetsnettet? En studie av Frelsesarmeens og Bymisjonens brukere". In Ivan Harsløf \& Sissel Seim eds, Fattigdommens dynamikk. Perspektiver på marginalisering i det norske samfunnet. Oslo: Universitetsforlaget, 2008.

Stolle, Dietlind. "Getting to trust. Analysis of the importance of institutions, families, personal experiences and group memberships". In Paul Dekker \& Eric M. Uslaner, eds. Social capital and participation in everyday life. London: Routledge, pp. 119-133, 2001.

Sztompka, Piotr. Trust: A Sociological Theory. Cambridge: Cambridge University Press, 1999.

Trägårdh, Lars. "Det civila samhällets karriär som vetenskapelig och politiskt begrepp i Sverige". Tidsskrift for samfunnsforskning, No.4, 2008: 576-591. Print.

Uslaner, Eric. The Moral Foundations of Trust. Cambridge: Cambridge University Press, 2002.

Veenhoven, Ruut. Happiness in nations: Subjective appreciation of life in 56 nations 19461992. 1993. Rotterdam : Erasmus University.eur.nI. Web. 6. August 2009. http://www2.eur.nl/fsw/research/veenhoven/Pub1990s/93b-part1.pdf. 
. "The study of life satisfaction". In William E. Saris, Ruut Veenhoven, Annette C. Scherpenzeel, \& Brendan Bunting eds, A comparative study of satisfaction with life in Europe. Eötvös University Press, 1996, pp 11-46. eur.nl. Web 6. August 2009. http://www2.eur.nl/fsw/research/veenhoven/Pub1990s/96d-full.pdf

Wahl, Astrid Klopstad. "Herths håpsindeks". Tidsskrift for Norsk Psykologiforening No 3, 2007: 273-274. Print.

Wel, Kjetil van der, eds, Sille Ohrem Naper, Marit Slagsvold, Borghild Løyland, Ivar Lødemel \& Espen Dahl. Funksjonsevne blant langtidsmottakere av sosialhjelp, HiO-rapport nr 29. Oslo: Høgskolen i Oslo, 2006.

Welch, Michael R, Roberto E. N. Riveria, Brian P. Conway, Jennifer Yonkoski, Paul M. Lupton \& Russel Giancola. "Determinants and Consequences of Social Trust". Sociological Inquiry 75, No. 4. 2005: 453-473. Print.

Aaslund, Håvard. Mestring og marginalisering. Opplevd kontroll og håp blant brukere av frivillige hjelpetiltak. Masteroppgave i sosialt arbeid. Oslo: Høgskolen i Oslo, 2008.

\section{Notes}

(Endnotes)

1. Quoting one of the study participants in the study when he was asked: "Generally speaking, would you say that most people can be trusted, or that you can't be too careful in dealing with people".

2. http://www. fre/sesarmeen.no/pages/side.aspx?nr=2218, (accessed 7.11.2008).

3. http://www.bymisjon.no/templates/Page 10432.aspx, (accessed 24.10.2008).

4. "Faith in people" :

1. "Some people say that most people can be trusted. Others say you can't be too careful in your dealings with people. How do you feel about it?"

2. "Would you say that most people are more inclined to help others or more inclined to look out for themselves?"

3. "If you don't watch your self, people will take advantage of you?"

4. "No one is going to care much what happens to you, when you get right down to it."

5. "Human nature is fundamentally cooperative?" (Rosenberg 1956:690).

5. http://www.regjeringen.no/nb/dep/hod/tema/rus/rusmidler-i-norge. $h$ tml?id=439352, (accessed 23.10.2008).

6. http://www.regjeringen.no/en/dep/hod/Subjects/alcohol-and-drug-addiction.html?id=1130 (accessed 18.3.2009).

7. http://www.regjeringen.no/en/dep/hod/documents/reports-and-plans/plans/2009/norwegian-national-action-planon-alcoho.html?id=549775, (accessed 30.3.2009). 